\title{
PROSTOROVÁ ANALÝZA PROJEKTŮ OPERAČNÍHO PROGRAMU VZDĚLÁVÁNÍ PRO KONKURENCESCHOPNOST
}

\author{
Oldřich Hájek, Jiří Novosák, Kateřina Šebestová, Šárka Hrabinová
}

\section{Klíčová slova:}

Kohezní politika, konvergence, lidský kapitál, Česká republika, vzdělávání

\section{Key Words:}

Cohesion policy, convergence, human capital, Czech Republic, education

\begin{abstract}
Abstrakt
Lidský kapitál představuje jeden z hlavních faktorů současných úvah o příčinách existence regionálních disparit a o stimulaci regionálního rozvoje. V tomto ohledu je proces tvorby lidského kapitálu spojován se zvyšováním produktivity, přičemž tvorba lidského kapitálu je založena na procesech vzdělávání a učení. Lidský kapitál je současně vnímán jako jeden z významných faktorů regionální diferenciace a jako takový získal své pevné místo v kohezní politice, která usiluje o redukci prostorových disparit. Tento článek se zaměřil na prostorovou analýzu projektů podpořených z Operačního programu Vzdělávání pro konkurenceschopnosti, který lze vnímat jako nejvíce relevantní pro problematiku lidského kapitálu a vzdělávání mezi českými operačními programy. Poznatky analýzy ukázaly na jistý stupeň nejednoznačnosti závěrů analýzy vzhledem ke konvergenčnímu cíli kohezní politiky. Takto byly projekty alokovány ve všech okresech České republiky, ale současně lze identifikovat významný vliv faktoru sídelní hierarchie. Zásadní roli v regionální diferenciaci rovněž hraje absorpční kapacita institucí terciárního vzdělávání.
\end{abstract}

\begin{abstract}
Human capital belongs to main factors when discussing causes of regional disparities on one hand and the ways how to stimulate regional development on the other. In this regard, the process of human capital building is traditionally connected with increasing productivity. It is noteworthy that the process of human capital building is based on education and learning. Moreover, human capital is perceived as an important factor of regional differentiation. Then, it is not surprising that human capital was firmly positioned in the fundamental conceptual framework of European cohesion policy with its goal to reduce spatial disparities. This article is focused on spatial analysis of projects supported from the Operational Programme Education for Competiveness. Just this Programme may be regarded as the most relevant Czech operational programme related to the themes human capital and education. The main findings of our analysis are a bit ambivalent when considering the convergence goal of cohesion policy. Thus, the projects were allocated in all Czech districts. However, an important influence of settlement hierarchy may be identified. In addition, the absorption capacity of tertiary education institutions plays a substantial role in regional differentiation.
\end{abstract}

\section{Úvod}

Veřejný sektor disponuje širokou paletou nástrojů pro ovlivňování směřování regionálního a místního rozvoje. V návaznosti na tuto skutečnost byla vytvořena řada typologií nástrojů regionálního a místního rozvoje (viz např. HOOD 2007, DRIESEN 2006, McGUIRE 2000), v níž své nezastupitelné místo získaly rovněž veřejné výdaje určené na zvyšování kvality 
lidského kapitálu prostřednictvím vzdělávání. Investice do lidského kapitálu jsou v tomto ohledu spojovány se zvyšováním produktivity ekonomických činností jako jednoho z rozhodujících faktorů konkurenceschopnosti území (viz např. ACS et al. 2007, BRONZINI, PISELLI 2009). Poznání významu lidského kapitálu jako faktoru rozvoje území stojí v pozadí začlenění problematiky vzdělávání mezi témata, na něž je alokována část prostředkủ evropské kohezní politiky a to $\mathrm{v}$ rámci výdajů Evropského sociálního fondu. Za pozornost $\mathrm{v}$ tomto směru stojí ta skutečnost, že na problematiku lidského kapitálu je v programovém období 2007-2013 vyčleněn stejný, 8 procentní, podíl finančních prostředků z celkového rozpočtu kohezní politiky v relativně zaostávajících i relativně vyspělých regionech Evropské unie (viz BARCA 2009).

Česká republika není v otázce začlenění problematiky lidského kapitálu a vzdělávání do svého rámce implementace kohezní politiky výjimkou, když v architektuře strategických dokumentů je v tomto ohledu relevantní zejména Operační program Vzdělávání pro konkurenceschopnost (dále jen $\mathrm{OP} \mathrm{VK}$ ). A právě analýza projektů podpořených z $\mathrm{OP} \mathrm{VK}$ je předmětem zájmu tohoto článku, jehož hlavním cílem je zhodnotit prostorové souvislosti alokace finančních prostředků z OP VK a to v kontextu jednoho z hlavních cílů kohezní politiky - snižování regionálních disparit. Článek je strukturován následujícím způsobem. První kapitola se zabývá významem lidského kapitálu a vzdělávání v současných rozvojových konceptech a to v kontextu konvergenčního cíle kohezní politiky. Druhá kapitola hodnotí postavení OP VK ve struktuře operačních programů České republiky a představuje metodiku analýzy projektů. Třetí kapitola představuje hlavní závěry prostorové analýzy k listopadu 2010 schválených projektů OP VK v kontextu konvergenčního cíle kohezní politiky. Poslední kapitola shrnuje hlavní poznatky.

\section{Lidský kapitál, vzdělávání, regionální rozvoj a kohezní politika Evropské unie}

Lidský kapitál představuje jeden ze stěžejních faktorů současných úvah týkajících se rozvojového paradigmatu. MOHAN, MOHAN (2002) definují pojem lidský kapitál v podobě schopností a kompetencí jednotlivce, které jsou získávány procesem vzdělávání a učení. V souladu s posunem vnímání technologického pokroku jako endogenního faktoru rozvojových teorií se přitom zájem o lidský kapitál a tím i o vzdělávání zvyšuje (viz MATHUR 1999, NIJKAMP et al. 2010). Takto např́iklad MATHUR (1999) tvrdí, že růst zaměstnanosti a př́jmu regionu je spojen s investicemi do lidských zdrojů pro akumulaci lidského kapitálu, tj. kvalifikované pracovní síly. Lidský kapitál následně představuje základní vstup pro tvorbu znalostí a inovací a současně vytváří předpoklady pro difúzi inovací, mimo jiné na bázi podnikatelského milieu. Současně dochází ke zvyšování ekonomické produktivity (TEIXEIRA 2005).

Problematika vztahů lidského kapitálu a rozvoje v sobě neoddělitelně obsahuje regionální dimenzi, když moderní teorie ekonomického růstu tvrdí, že růst bude větší v regionech schopných akumulovat lidský kapitál a současně zvyšovat svou zásobárnu znalostí (viz napřr. MATHUR 1999, GOTTLIEB, FOGARTY 2003, TVRDOŇ 2008). Takto např́klad DI LIBERTI (2008), HUČKA a kol. (2009) označuje lidský kapitál jako významný diferencující faktor ekonomické výkonnosti jednotlivých regionů a rovněž DE LA FUENTE, VIVES (1996) hovoří o vzdělání jako významném indikátoru regionálních disparit. GOTTLIEB, FOGARTY (2003) dále spojují prostorovou dimenzi lidského kapitálu a vzdělávání se sídelní hierarchií, když poukazují na výhody velkých metropolitních oblastí spojené s rychlejším procesem prostorové difúze na bázi četnosti kontaktů. 
Předchozí poznatky týkající se vztahů lidského kapitálu a regionálního rozvoje stojí v pozadí úvah o utváření politik zaměřených na tvorbu lidského kapitálu. MATHUR (1999) shrnuje racionálno takových politik prostřednictvím nesouladu relací mezi soukromými a společenskými pozitivity, které snižují zájem soukromého sektoru investovat do procesu tvorby lidského kapitálu, např́klad pod hrozbou odchodu lidského kapitálu ke konkurenčnímu subjektu. Vedle toto DI LIBERTI (2008) uvádí řadu typicky společenských pozitiv, které jsou spojeny s tvorbou lidského kapitálu v území, a ke kterým se řadí mimo jiné sociální koheze, redukce kriminality či posilování informovaného politického rozhodování. Poslední prvek nás posunuje směrem $\mathrm{k}$ myšlence sociálního kapitálu jako v současnosti mimořádně módního rozvojového konceptu (viz např. CALLOIS, AUBERT 2007). Sociální kapitál je oproti lidskému kapitálu chápán jako vlastnictví společnosti a znak společenského života, který umožňuje jeho nositelům jednat efektivněji ve směru sdílených cílů a to na bázi vytvořených norem a důvěry (MOHAN, MOHAN 2002). CALLOIS, AUBERT (2007) zdůrazňují, že rozvinutý sociální kapitál snižuje transakční náklady a usnadňuje difúzní procesy v území.

Na výše uvedeném myšlenkovém základě se stávají opodstatněné politiky zaměřené na rozvoj lidského kapitálu $\mathrm{v}$ regionech a to $\mathrm{v}$ kontextu sbližování rozdílů $\mathrm{v}$ jejich ekonomické výkonnosti. Takto není překvapením, že téma lidský kapitál a vzdělávání našlo své místo rovněž v kohezní politice Evropské unie, pro kterou je konvergence ekonomické výkonnosti regionů jedním z klíčových cílů. Problematikou konvergence ekonomické výkonnosti regionů Evropské unie se zabývala celá řada prací, přičemž HÁJEK, NOVOSÁK (2011) poukazují na ambivalentnost poznatků těchto studií. Takto bylo mimo jiné pozorováno snižování regionálních disparit na národní úrovni a naopak prohlubování regionálních disparit uvnitř jednotlivých zemí (např. PUGICERVER-PEŇALVER 2007, BARCA 2009, DE LA FUENTE, VIVES 1996), které souvisí rovněž s prohlubováním rozdílů mezi jádrovými a periferními oblastmi členských zemí (napřr. BACHTLER, GORZELAK 2007). BACHTLER, GORZELAK (2007) přitom tvrdí, že uvedený trend je zvlášt' intenzivní v př́ípadě nově přistoupivších zemí Evropské unie.

Poslední odstavec vytváří teoretický rámec pro další směřování tohoto článku. Téma lidský kapitál a vzdělávání je celkem přirozeně součástí architektury českých operačních programů. $\mathrm{K}$ této problematice má svůj vztah více operačních programů (např. Operační program Věda a výzkum pro inovace, Operační program Lidské zdroje a zaměstnanost) k nimž patř́ rovněž OP VK. Další text se proto blíže věnuje tomuto operačnímu programu, přičemž výzkumná otázka se ptá, jaké je prostorové rozložení hlavních př́ijemců podpory k listopadu 2010 schválených projektů. V souladu s výše formulovanými poznatky předpokládáme vyšší koncentraci projektů $\mathrm{v}$ ekonomicky relativně vyspělejších regionech a hlavních metropolitních oblastech České republiky.

\section{OP VK - základní představení a metodika analýzy projektů}

V programovém období 2007-2013 získala Česká republika ojedinělou př́ležitost čerpat finanční prostředky kohezní politiky (viz např. BLAŽEK 2006, WOKOUN 2007) v kontextu celkového objemu disponibilních zdrojů, který činí 26,7 mld. EUR. Celková finanční alokace je rozdělena mezi osm sektorových operačních programů včetně OP VK, sedm regionálních operačních programů, sedm operačních programů cíle Evropská územní spolupráce a dvou operačních programů určených pro Prahu. 
Obrázek 1 znázorňuje rozdělení prostředků kohezní politiky mezi jednotlivé operační programy České republiky v programovém období 2007-2013. Takto je patrný relativně nižší objem finančních prostředků určených pro OP VK ve srovnání s dalšími sektorovými operačními programy, zejména v oblasti infrastrukturních projekti̊. Poznamenejme, že finanční alokace ve výši 1,8 mld. EUR připadající na OP VK odpovídá cca 7 procentnímu podílu z celkové alokace České republiky, což je číslo více méně srovnatelné s podílem tématu lidský kapitál $\mathrm{v}$ rámci celé kohezní politiky. Tabulka 1 pak představuje rozdělení finanční alokace OP VK mezi 5 prioritních os, které operační program utváŕí.

Obrázek 1: Finanční alokace prostř̌edků kohezní politiky mezi operační programy České republiky v programovém období 2007-2013

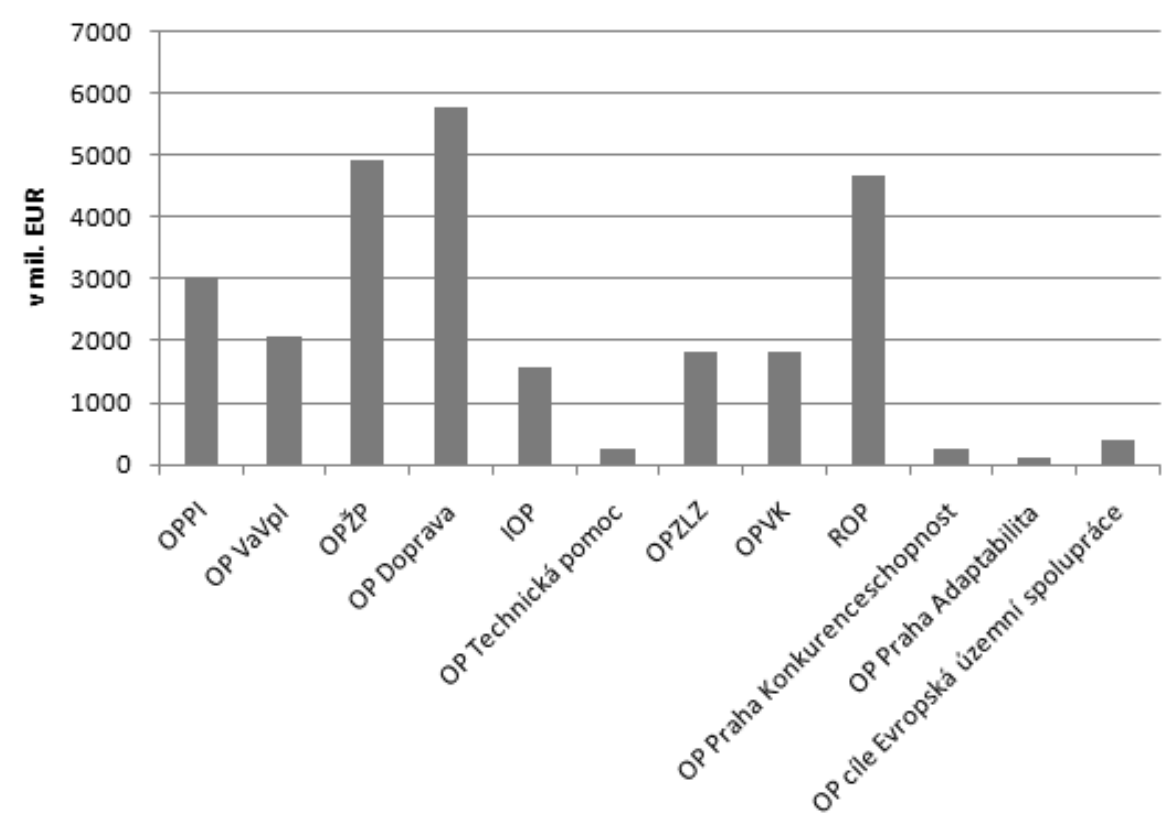

Zdroj: MMR (2007), HÁJEK, NOVOSÁK (2011)

Tabulka 1: Finanční alokace prioritních os OP VK

\begin{tabular}{|l|c|c|}
\hline \multicolumn{1}{|c|}{ Prioritní osa } & Finanční alokace & Podíl na celkové alokaci \\
\hline Počáteční vzdělávání & 612 mil. EUR & $34 \%$ \\
\hline Terciární vzdělávání, věda a výzkum & 627 mil. EUR & $34 \%$ \\
\hline Další vzdělávání & 290 mil. EUR & $16 \%$ \\
\hline Systémový rámec celoživotního učení & 227 mil. EUR & $12 \%$ \\
\hline Technická pomoc & 73 mil. EUR & $4 \%$ \\
\hline Celkem & $\mathbf{1 , 8}$ mld. EUR & $\mathbf{1 0 0} \%$ \\
\hline
\end{tabular}

Pozn.: Finanční alokace zahrnuje pouze příspěvek Společenství

Zdroj: MŠMT (2009)

Výše uvedené poznatky představují základní rámec pro předkládaní projektů do OP VK v programovém období 2007-2013. Další kapitola blíže analyzuje k listopadu 2010 schválené projekty tak, jak byly zveřejněny administrátorem programu - Ministerstvem školství, mládeže a tělovýchovy (dále jen MŠMT). Metodicky analýza vychází z datové matice schválených projektů, kdy řádky matice obsahují jednotlivé projekty a sloupce jejich vybrané atributy. Primární datová matice zveřejněná MŠMT obsahovala atributy vztažené k názvu projektu, hlavnímu př́jemci podpory a alokované částce. Tyto atributy byly následně doplněny o: 
- typ př́jemce podpory na bázi reklasifikace informací o jejich názvech,

- aspekt sídelní hierarchie reprezentovaný postavením obce se sídlem hlavního př́jemce podpory v rámci administrativně-správního členění České republiky,

- prostorový aspekt reprezentovaný obcí, okresem a krajem sídla hlavního př́ijemce podpory.

Tabulka 2: Hodnoty sledovaných atributů k listopadu 2010 schválených projektů OP VK

\begin{tabular}{|c|c|}
\hline Atribut & Hodnota \\
\hline Typ hlavního př́ijemce & $\begin{array}{l}\text { 1. Základní škola } \\
\text { 2. Střední škola } \\
\text { 3. Terciární vzdělávání } \\
\text { 4. Další subjekty (neziskový sektor, podnikatelský sektor, } \\
\text { veřejný sektor) }\end{array}$ \\
\hline Aspekt sídelní hierarchie - sídlo hlavního př́ijemce & $\begin{array}{l}\text { 1. Praha, Brno, Ostrava } \\
\text { 2. Další krajská města } \\
\text { 3. Další obce nad } 20000 \text { obyvatel } \\
\text { 4. Ostatní obce }\end{array}$ \\
\hline Prostorový aspekt - sídlo hlavního příjemce & Obec, okres, kraj \\
\hline Alokovaná částka & Výše částky v Kč \\
\hline
\end{tabular}

Zdroj: Vlastní zpracování

Hodnoty, kterých mohly jednotlivé atributy nabývat, shrnuje tabulka 2. Následné vyhodnocení je založeno na aplikaci základních metod deskriptivní statistiky s vizualizací vybraných závěrů v prostředí GIS. Poznamenejme a zdůrazněme přitom, že prostorová analýza se dotýká výhradně sídla hlavního př́jemce podpory a v tomto kontextu je třeba vnímat omezení hodnocení územních dopadů ve dvou směrech. Primárně se jedná o možný nesoulad sídla hlavního př́jemce a území dopadu a současně není $\mathrm{v}$ analýze zohledněn princip partnerství s alokací části poskytnutých finančních prostředků projektů partnerům. Přes tato omezení považujeme dále formulované poznatky za relevantní pro vyhodnocení námi formulované výzkumné otázky.

\section{Analýza projektů OP VK - prostorové souvislosti}

Do analýzy projektů OP VK bylo zařazeno celkem 2905 projektů s celkovou finanční alokací 17,2 mld. Kč. Z hlediska typu hlavního př́ijemce připadal nejvyšší počet projektů na základní školy, které byly následované dalšími subjekty, institucemi terciárního vzdělávání a středními školami (viz tabulka 3). Jiné pořadí přineslo kritérium celkového objemu alokovaných prostředků, kdy nejvyšší objem prostředků připadal na kategorii dalších subjektů, následovaných institucemi terciárního vzdělávání, základními školami a středními školami (viz tabulka 3). Takto je současně zjevná skutečnost, že podpořené projekty základních a středních škol byly z hlediska celkové alokované částky menší než projekty institucí terciárního vzdělávání a dalších subjektů.

Tabulka 3: Podíly jednotlivých typů hlavních př́jemců na počtu projektů a alokované částce

\begin{tabular}{|l|c|c|}
\hline \multicolumn{1}{|c|}{ Typ hlavního př́jemce } & Podíl na počtu projektů & Podíl na celkové částce \\
\hline Základní školy & $42 \%$ & $12 \%$ \\
\hline Střední školy & $17 \%$ & $11 \%$ \\
\hline Terciární vzdělávání & $17 \%$ & $27 \%$ \\
\hline Další subjekty & $25 \%$ & $50 \%$ \\
\hline
\end{tabular}

Zdroj: Vlastní zpracování na základě datové matice MŠMT - internetové stránky MŠMT, stav k listopadu 2010 
Aspekt sídelní hierarchie přináší podobně jako $\mathrm{v}$ př́ípadě typu hlavního př́ijemce rozdílné poznatky vzhledem k počtu projektů na jedné straně a celkové alokované částce na straně druhé. Nejvyšší počet podpořených projektů připadl na hlavního příjemce se sídlem mimo velká i středně velká města České republiky (viz tabulka 4). Naopak nejvyšší objem finančních prostř̌edků byl alokován na projekty hlavních prríjemců ze tří největších měst České republiky (viz tabulka 4). Obecně lze proto tvrdit, že finančně nejnáročnější projekty jsou spojeny s hlavními žadateli se sídlem v největších městech České republiky, zatímco projekty OP VK realizované v malých obcích České republiky jsou objemem alokovaných finančních prostředků relativně malé. Současně stojí za pozornost srovnání podílů jednotlivých kategorií sídel hlavních prŕjemců na počtu projektů a celkové alokované částce s podíly těchto kategorií na počtu obyvatel České republiky. Ukazuje se, že největší města mají významně vyšší podíl vzhledem k celkové alokované částce a další krajská města pak vzhledem k počtu projektů.

Tabulka 4: Podíly jednotlivých kategorií sídel hlavních příjemců na počtu projektů, alokované částce a počtu obyvatel České republiky

\begin{tabular}{|l|c|c|c|}
\hline \multirow{2}{*}{\multicolumn{1}{c|}{ Typ hlavního př́jemce }} & \multicolumn{2}{c|}{ Podíl } \\
\cline { 2 - 4 } & na počtu projektů & na celkové částce & na počtu obyvatel \\
\hline Praha, Brno, Ostrava & $21 \%$ & $49 \%$ & $18 \%$ \\
\hline Další krajská města & $21 \%$ & $23 \%$ & $9 \%$ \\
\hline Další obce nad 20 000 obyvatel & $16 \%$ & $13 \%$ & $17 \%$ \\
\hline Další obce & $41 \%$ & $15 \%$ & $56 \%$ \\
\hline
\end{tabular}

Zdroj: Vlastní zpracování na základě datové matice MŠMT - internetové stránky MŠMT, stav k listopadu 2010; ČSÚ pro počet obyvatel obcí České republiky v roce 2010

Prostorový aspekt analýzy byl hodnocen na krajské a okresní úrovni. Obrázek 2 znázorn̆uje prostorovou distribuci počtu a finanční alokace projektů OP VK na bázi sídla hlavního př́ijemce podle krajů České republiky. Hlavní poznatky v tomto směru lze shrnout následujícím způsobem:

- Absolutně nejvyšší počet projektů připadl na hlavní př́ijemce se sídlem v Jihomoravském, Moravskoslezském a Olomouckém kraji. Naopak nejnižší počty projektů vykázali hlavní prŕjemci se sídlem v Karlovarském, Plzeňském a Zlínském kraji.

- Nejvyšší objem finanční alokace na 1 obyvatele připadl na hlavní př́jemce se sídlem v Praze, Jihomoravském a Olomouckém kraji. Poznatky vztahující se k Praze je ovšem třeba brát $\mathrm{s}$ rezervou s ohledem na skutečnost, že území dopadu těchto projektů je mimo území hlavního města. Naopak nejnižší objem finanční alokace připadající na 1 obyvatele vykázaly kraje Středočeský, Karlovarský, Zlínský a Jihočeský.

Obrázek 2 dále poukazuje na některá specifika krajů vzhledem k typům hlavního př́ijemce. Primárně je možné poukázat na dominantní podíl kategorie dalších subjektů ve struktuře typů hlavních př́jemců podpory hlavního města Prahy. Takto lze identifikovat jednu z možných strategií subjektů se sídlem v Praze, jak řešit otázku nezahrnutí hlavního města do čerpání prostředků cíle Konvergence. Druhým poznatkem je velmi vysoký podíl institucí terciárního vzdělávání ve struktuře typů hlavních př́ijemců podpory Jihomoravského a Olomouckého kraje. Obdobné instituce dalších krajů vykázaly výrazně nižšś zastoupení v tomto směru. Třetí poznatek je spojen s relativně častějším zastoupením základních a středních škol ve struktuře typů hlavních př́ijemců podpory v př́ípadě perifernějších regionů České republiky (např. Jihočeský kraj, Karlovarský kraj, Zlínský kraj), přičemž právě tyto regiony rovněž vykázaly nejnižší objem alokovaných prostředků na 1 obyvatele kraje. Celkově je možné pozorovat 
rozdíly $\mathrm{v}$ počtu schválených projektů i objemu alokovaných prostředků v závislosti na ekonomické výkonnosti krajů, nicméně tento vztah v žádném př́padě není jednoznačný (viz např. postavení Středočeského kraje na jedné straně a Olomouckého kraje na straně druhé).

Obrázek 2: Prostorová distribuce počtu a finanční alokace projektů OP VK na bázi sídla hlavního př́ijemce podle krajů České republiky

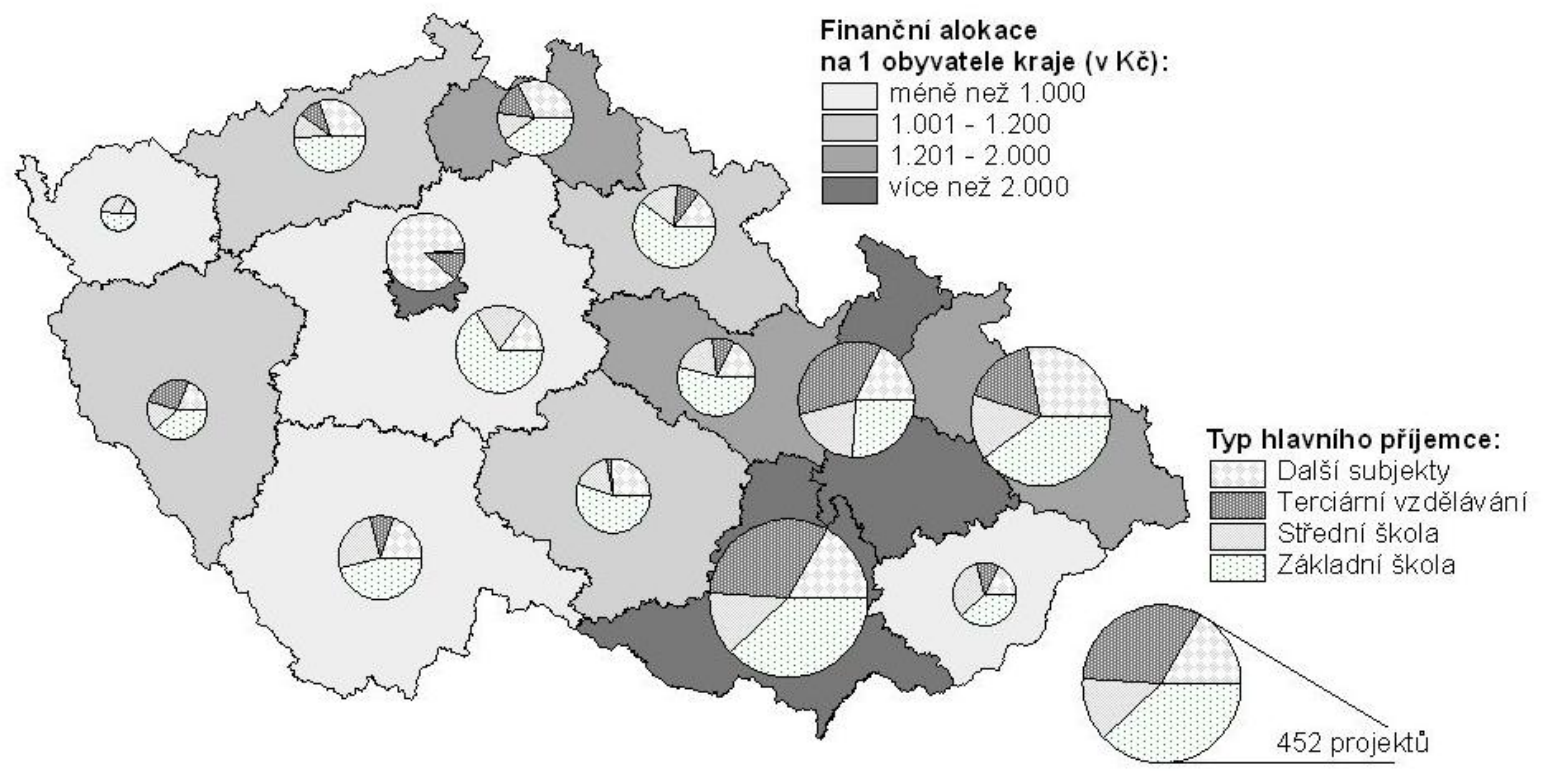

Zdroj: Vlastní zpracování na základě datové matice MŠMT - internetové stránky MŠMT, stav k listopadu 2010; ČSÚ pro počet obyvatel krajů České republiky v roce 2010

\section{Obrázek 3: Prostorová distribuce počtu a finanční alokace projektů OP VK na bázi sídla hlavního př́ijemce podle okresů České republiky}

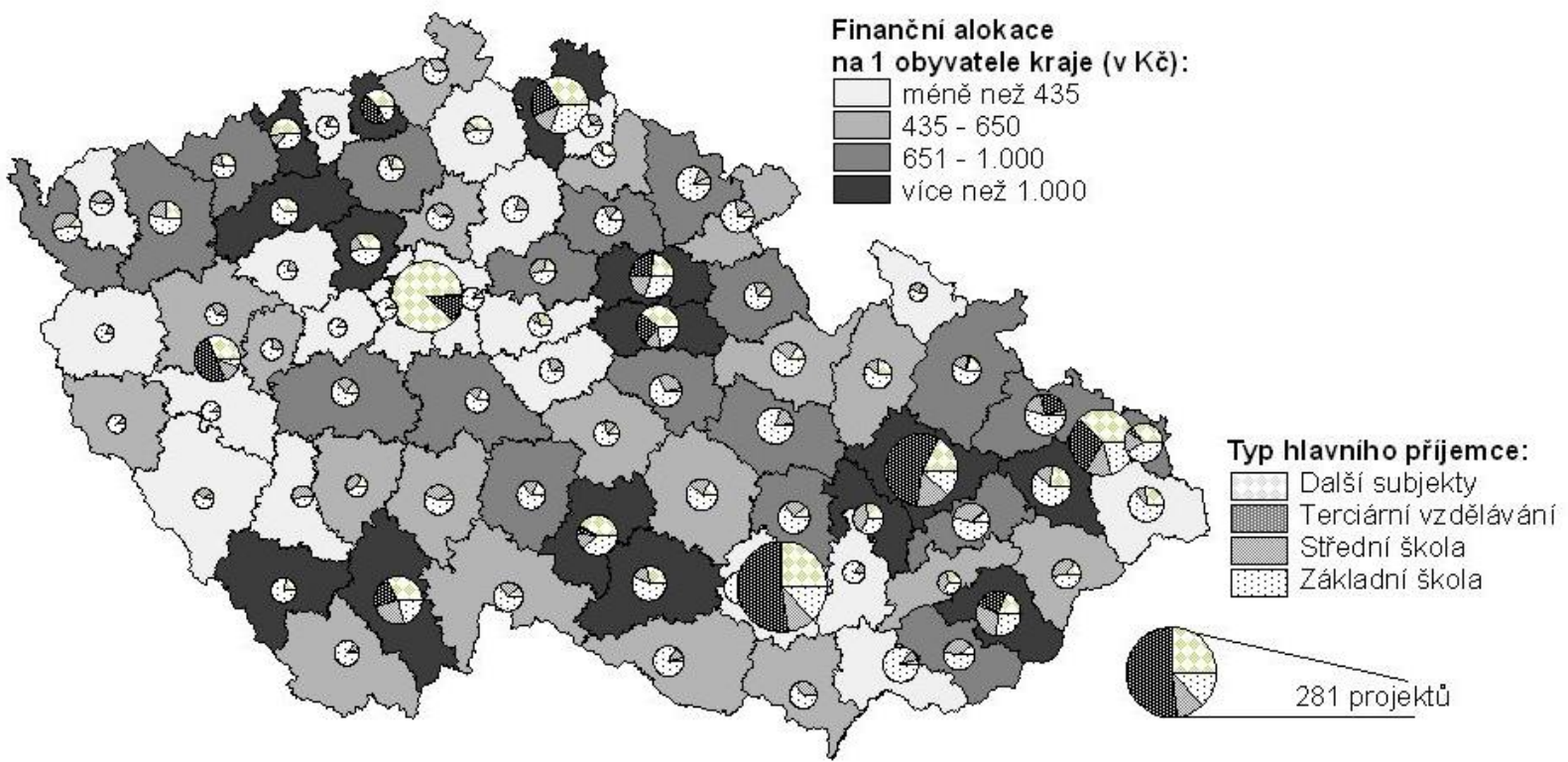

Zdroj: Vlastní zpracování na základě datové matice MŠMT - internetové stránky MŠMT, stav k listopadu 2010; ČSÚ pro počet obyvatel okresů České republiky v roce 2010 
Prostorová dekompozice sledovaného jevu na okresní úrovni jednak potvrzuje a jednak rozvádí poznatky formulované pro úroveň krajskou. Takto je možné pozorovat absolutně nejvyšší počet schválených projektů v okresech Brno-město a Olomouc, přičemž oba tyto okresy vykázaly relativně velmi vysoký podíl institucí terciárního vzdělávání ve struktuře typů hlavních př́ijemců. Celková relativní alokovaná částka přepočtená na 1 obyvatele okresů naznačuje existenci rozdílů mezi okresy krajských měst s relativně vyšší hodnotou na jedné straně a ostatními okresy s relativně nižší hodnotou na straně druhé. Za zásadní lze v tomto směru označit zastoupení institucí terciérního vzdělávání ve struktuře typů hlavního příjemce okresů krajských měst s výjimkou Karlových Varů (viz rovněž tabulka 5 pro srovnání pořadí 10 okresů s nejvyšší alokovanou částkou na 1 obyvatele pro tři kategorie typů hlavních př́ijemců podpory). Konečně za pozornost stojí ta skutečnost, že všechny okresy České republiky vykázaly existenci alespoň jednoho schváleného projektu OP VK.

Tabulka 5: Okresy s nejvyšší alokovanou částkou na 1 obyvatele na bázi sídla vybraných typů hlavních př́ijemců podpory

\begin{tabular}{|c|l|l|l|}
\hline Pořadí & \multicolumn{1}{|c|}{ Základní školy } & \multicolumn{1}{c|}{ Stř̌ední školy } & \multicolumn{1}{c|}{ Terciární vzdělávání } \\
\hline 1. & Svitavy & Olomouc & Brno-město \\
\hline 2. & Jihlava & Přerov & Olomouc \\
\hline 3. & Prachatice & Zlín & Plzeň-město \\
\hline 4. & Liberec & Most & Liberec \\
\hline 5. & Havlíčkův Brod & Uherské Hradiště & Pardubice \\
\hline 6. & Chrudim & Děčín & Ostrava-město \\
\hline 7. & Brno-město & Jičín & Ústí nad Labem \\
\hline 8. & Třebíč & Litoměřice & Hradec Králové \\
\hline 9. & Příbram & Cheb & Zlín \\
\hline 10. & Hradec Králové & Prostějov & České Budějovice \\
\hline
\end{tabular}

Zdroj: Vlastní zpracování na základě datové matice MŠMT - internetové stránky MŠMT, stav k listopadu 2010

\section{Závěr}

Lidský kapitál představuje jeden z hlavních faktorů současných úvah jednak o možnostech stimulace regionálního rozvoje a jednak o př́činách existence regionálních disparit. V tomto ohledu je proces tvorby lidského kapitálu spojován se zvyšováním produktivity, přičemž tvorba lidského kapitálu je založena na procesech vzdělávání a učení. Opodstatněnou se takto stává snaha zasadit problematiku tvorby lidského kapitálu a vzdělávání rovněž v rámci evropské kohezní politiky, která mimo jiné usiluje o zvyšování územní koheze prostřednictvím snižování regionálních disparit. Česká republika není v tomto ohledu výjimkou, když témata lidského kapitálu a vzdělávání mají své pevné místo v její architektuře operačních programů a to zejména v nastavení cílů OP VK.

Hlavní zájem tohoto článku se orientoval na zhodnocení prostorových souvislostí alokace finanční podpory k listopadu 2010 schválených projektů OP VK a to na bázi sídla hlavního př́jemce podpory. V první kapitole jsme přitom formulovali předpoklad o vyšší koncentraci projektů v ekonomicky relativně vyspělejších regionech a hlavních metropolitních oblastech České republiky a to s ohledem na očekávanou vyšší absorpční schopnost těchto území. Poznatky analýzy ukázaly jen na částečnou platnost uvedených předpokladů, kdy nejvyšší hodnoty počtu projektů i finanční alokace na 1 obyvatele vykázaly ekonomicky relativně vyspělejší Jihomoravský kraj na straně jedné a relativně zaostalejší kraj Olomoucký na straně druhé. Současně poukažme na skutečnost, že projekty OP VK byly alokovány ve všech 
okresech České republiky a $\mathrm{k}$ diferenciaci dochází teprve v oblasti terciárního vzdělávání v návaznosti na sídelní hierarchii České republiky. Př́íklad Univerzity Palackého v Olomouci přitom ukazuje na možnosti uchopení prŕležitostí kohezní politiky v př́ípadě dostatečné absorpční kapacity dobře připraveného aktéra v relativně zaostávajícím regionu. Tento předpoklad se zdá být naplněn na mnohem nižší úrovni v prŕípadě dalších periferních regionů České republiky.

Námi formulované poznatky jsou do jisté míry zatíženy hlavním nedostatkem provedené analýzy, kdy byl prostorový aspekt zohledněn prostřednictvím sídla hlavního př́jemce podpory bez zohlednění širších územních dopadů. Tento aspekt je nejsilněji pocit'ován v případě kategorii dalších př́ijemců podpory, jejichž sídlo je velmi často lokalizováno na území hlavního města Prahy, ale vlastní projekty realizovány v jiných krajích České republiky a svůj význam má rovněž v rámci sledování principu partnerství. A právě v tomto směru se bude orientovat náš další výzkum, který se zaměří na prohloubení prostorové analýzy projektů OP VK prostřednictvím zohlednění míst realizace vlastních projektů. Vedle toho se bude náš výzkum orientovat na rozšíření studovaného tématu o další operační programy relevantní pro téma lidské zdroje.

Tento př́spěvek byl zpracován jako jeden $\mathrm{z}$ výstupů projektu financovaného Interní grantovou agenturou UTB ve Zlíně č. IGA/50/FaME/11/A "Analýza naplňování konvergenčního cíle kohezní politiky v ČR v programovém období 2007-2013".

\section{Literatura}

[1] ACS, Z. et al. Could the Irish miracle be repeated in Hungary? Small Business Economics, 2007, vol. 28, no. 2, s. 123-142.

[2] BACHTLER, J., GORZELAK, G. Reforming EU cohesion policy. A reappraisal of the performance of the structural funds. Policy Studies, 2007, vol. 28, no. 4, s. 309-326.

[3] BARCA, F. An agenda for a reformed cohesion policy. A place-based approach to meeting European Union challenges and expectations. Brussels: European Commission, 2009, $244 \mathrm{~s}$.

[4] BLAŽEK, J. Jakou regionální politiku potřebujeme po vstupu do EU? In Šest let regionální politiky v $\check{C} R$. Šance a limity. Brno: Masarykova univerzita v Brně, 2006, s. 37-48.

[5] BRONZINI, R., PISELLI, P. Determinants of long-run regional productivity with geographical spillovers: the role of $\mathrm{R} \& \mathrm{D}$, human capital and public infrastructure. Regional Science and Urban Economics, 2009, vol. 39, no. 2, s. 187-199.

[6] CALlOIS, J. M., AUBERT, F. Towards indicators of social capital for regional development issues: the case of French rural areas. Regional Studies, 2007, vol. 41, no. 6, s. 809-821.

[7] DE LA FUENTE, A., VIVES, X. Infrastructure and education as instruments of regional policy: evidence from Spain. Economic Policy, 1995, vol. 10, no. 20, s. 13-51.

[8] DI LIBERTO, A. Education and Italian regional development. Economics of Education Review, 2008, vol. 27, no. 1, s. 94-107.

[9] DRIESEN, D. Economic instruments for sustainable development. In Environmental law for sustainability: a critical reader. Oxford: Hart Publishing, 2006, s. 277-308.

[10] GOTTLIEB, P. D., FOGARTY, M. Educational attainment and metropolitan growth. Economic Development Quarterly, 2003, vol. 17, no. 4, s. 325-336.

[11] HÁJEK, O., NOVOSÁK, J. Kohezní politika v širšich souvislostech. Žilina: Georg, 2011, $216 \mathrm{~s}$. 
[12] HOOD, C. Intellectual obsolescence and intellectual makeovers: reflections on the tools of government after two decades. Governance: An International Journal of Policy, Administration, and Institutions, 2007, vol. 20, no. 1, s. 127-144.

[13] HUČKA, M., KUTSCHERAUER, A., SUCHÁČEK, J. Teoreticko-metodologické aspekty regionálních disparit. Acta Academica Karviniensia, 2009, vol. 19, no. 2, s. $131-142$.

[14] MATHUR, V. K. Human capital-based strategy for regional economic development. Economic Development Quarterly, 1999, vol. 13, no. 3, s. 203-216.

[15] McGUIRE, M. Collaborative policy making and administration: the operational demands of local economic development. Economic Development Quarterly, 2000, vol. 14, no. 3, s. $278-291$.

[16] MMR. Národní strategický referenční rámec ČR 2007-2013. Praha: Ministerstvo pro místní rozvoj, 2007, $155 \mathrm{~s}$.

[17] MOHAN, G., MOHAN, J. Placing social capital. Progress in Human Geography, 2002, vol. 26, no. 2, s. 191-210.

[18] MŠMT. Př́ručka pro žadatele o finanční podporu z Operačního programu Vzdělávání pro konkurenceschopnost. Praha: Ministerstvo školství, mládeže a tělovýchovy, 2009, $130 \mathrm{~s}$.

[19] NIJKAMP, P., STIMSON, R., van HEMERT, P. Human capital as knowledge resource for regional development. Tijdschrift voor Economische en Sociale Geografie, 2010, vol. 101 , no. 5 , s. 491-493.

[20] PUGICERVER-PEŇALVER, M. C. The impact of structural funds policy on European regions' growth. A theoretical and empirical approach. The European Journal of Comparative Economics, 2007, vol. 4, no. 2, s. 179-208.

[21] TEIXEIRA, A. A. C. Measuring aggregate human capital in Portugal: 1960-2010. Portuguese Journal of Social Science, 2005, vol. 4, no. 2, s. 101-120.

[22] TVRDOŇ, M. Teoreticko-metodologická východiska dekompozice regionálních disparit ekonomické povahy. Acta Academica Karviniensia, 2008, vol. 18, no. 2, s. 216-225.

[23] WOKOUN, R. Regionální a strukturální politika (politika soudržnosti) Evropské unie v programovém období 2007-2013. Urbanismus a územní rozvoj, 2007, vol. 10, č. 1, s. 3-7.

Klasifikace JEL: R12, O18, R58, H23

RNDr. Oldřich Hájek, Ph.D.,

Odborný asistent, Ústav veřejné správy, regionálního rozvoje a práva

Fakulta managementu a ekonomiky

Univerzita Tomáše Bati ve Zlíně

Mostní 5139, 76001 Zlín

Email: hajek@fame.utb.cz

Mgr. Jiří Novosák, Ph.D.

Odborný asistent, Ústav veřejné správy, regionálního rozvoje a práva

Fakulta managementu a ekonomiky

Univerzita Tomáše Bati ve Zlíně

Mostní 5139, 76001 Zlín

Email:novosak@fame.utb.cz 


\section{Ing. Kateřina Šebestová}

Ústav veřejné správy, regionálního rozvoje a práva Fakulta managementu a ekonomiky

Univerzita Tomáše Bati ve Zlíně

Mostní 5139, 76001 Zlín

\section{Ing. Šárka Hrabinová}

Ústav veřejné správy, regionálního rozvoje a práva Fakulta managementu a ekonomiky

Univerzita Tomáše Bati ve Zlíně

Mostní 5139, 76001 Zlín 